家畜の の 双品吸

茅 根 士 郎*

双口吸虫は分類上, 双口吸虫上科 (Paramphistomoidea 上科）に位置して和り，双口吸虫上科には 3 科(Paramphistomidae 科, Gastrothylacidae 科, Brumptiidae 科) がありこの科はさらに 4 亜科 (Gastrothylacinae 亜科, Gastrodiscinae 亜科, Paramphistominae 亜科, Orthocoeliinae 亜科)に分類されている75). したがって,一口に 双口吸虫といっても, その種類はすこぶる多く, 哺乳類 に寄生する双口吸虫だけでも 40 属 150 種が存在すると いる礼る ${ }^{75)}$ ，また宿主となる哺乳類は家畜の反媰動物以 外にも人, サル, 豚, 馬, カバ, ゾウ, 海牛, ヌートリ ア，ミズハタネズミ（表 1）などきわめて多くの動物に 寄生がみられ，その寄生部位も胃の注かに，小腸，大 腸, 盲腸, 胆管, 胆囊など広範囲にわたっている.

このように多数の属種に分かれている双口吸虫の分 類は古くからたくさんの研究者によって行なわれてお り, 諸外国では, FISCHOEdER $\left(1901^{25)}, 1903^{26)}\right)$, STILes \& GoldBerger (1910) ${ }^{62)}$, MAPlestone (1923) ${ }^{47)}$, Stunkard $(1925)^{63)}$, Fuhrman $(1928)^{27)}$, Travassos
(1935) ${ }^{67)}$, NÄSMARK $(1937)^{49)}$, Price \& MCINTosh $(1944)^{56)}$, DAWES (1946) ${ }^{14)}$ などの研究があり，また日 本に括いては扮もに FukuI (1929) ${ }^{28)}$, Yamaguti (1939 73)，195374)，1971 $\left.{ }^{75)}\right)$ などによって行なわれている。 くに NÄSMARK は双口吸虫を同定するにあたって各属の 虫体の口吸盤, 生殖腔, 後吸盤の構造について, 中央縦 断切片の組織学的検査を実施し，系統的な観点から双口 吸虫を分類し，その後の研究者はほとんどが，彼の分類 基準にしたがっている，それでもな和双口吸虫の同定に ついては混乱がみられ，最近では形態学的面ばかりでは なく, 同属間での免疫学的 ${ }^{41)}$ 方向からも比較研究され て，種類の同定が検討されつつある.

双口吸虫症 (paramphistomiasis) については, 以前から 多数の症例が報告されている.とくに幼若な未成熟虫が 腸に寄生したために病害を起こす腸双口吸虫症（intestinalis paramphistomiasis) については BoRAY (1959) ${ }^{5)}$, DiNNIK $(1964)^{18)}$, HORAK (1971) ${ }^{35)}$ などの総説からも 明らかなように世界各地で発生し，牛，めん羊，山羊の

$$
\text { 表1世界にみられる双口吸虫 }
$$

\begin{tabular}{|c|c|c|c|}
\hline 類 & 中 間 宿 主 & 主 & 寄生部位 \\
\hline${ }^{\circ}$ Paramphistomum explanatum & *Gyraulus convexiusculus & 牛, 水牛 & 胆管, 胆囊 \\
\hline${ }^{\circ}$ Paramphistomum cervi & ***Physa alexandrina & 牛, アカジカ, バイソン & 胃 \\
\hline${ }^{\circ}$ Paramphistomum microbothium & *Bulunus alluaudi & 牛, 水牛, レイョウ & 胃 \\
\hline${ }^{\circ}$ Paramphistomum microbothrioides & **Stagnicola cubensis & 牛, めん羊 & 胃 \\
\hline${ }^{\circ}$ Gastrothylax crumenifer & *Gyraulus convexiusculus & コブ牛 & 胃 \\
\hline${ }^{\circ}$ Fischoederius elongatus & **Lymnaea luteola & 牛, 山羊 & 胃 \\
\hline${ }^{\circ}$ Gastrodiscus aegyptiacus & $\begin{array}{c}* * * * \text { Cleopatra bulimoides } \\
* \text { Bulinus forskalii }\end{array}$ & 馬, ロバ, イボイノシン & 大 腸 \\
\hline${ }^{\circ}$ Gastrodiscus secundus & *Indoplanorbis exustus & 馬，インドゾウ & 小腸，大腸 \\
\hline${ }^{\circ}$ Gastrodiscoides hominis & *Helicorbis coenosus & $\begin{array}{l}\text { 人, 豚, サル, ヌートリア } \\
\text { ミズハタネズミ }\end{array}$ & 大腸 \\
\hline${ }^{\circ}$ Homalogaster paloniae & *Polypylis hemisphaerula & 牛, 水牛, 山羊 & 盲 腸 \\
\hline${ }^{\circ}$ Watsonius watosoni & $* * *$ Physa $\mathrm{sp}$ & 人, サル & 十二指腸，空腸 \\
\hline${ }^{\circ}$ Nilocotyle circulare & 一 & カ バ & 胃 \\
\hline${ }^{\circ 0}$ Brumptia bicaudatum & - & アフリカゾウ, クロサイ & 一 \\
\hline${ }^{\circ}$ Pseudodiscus collinsi & *Indoplanorbis exustus & 馬，インドゾウ. & 結 腸 \\
\hline${ }^{\circ}$ Chiorchis fabaceus & - & 海 牛 & 一 \\
\hline
\end{tabular}

※ 分類は Yamaguti (1971) による

${ }^{\circ}$ Paramphistomidae 科 ${ }^{\circ} \mathrm{G}$ Gastrothylacidae 科 ${ }^{\circ 0}$ Brumptiidae 科

*Family Planorbidae ヒラマキガイ科＊*Family Lymnaeidae モノアラガイ科 ***Family Family Physidae サカマキガイ科 ****Family Thiaridae トウガタカワニナ科

* 麻布獣医科大学（神奈川県相模原市㴊野辺1-17-71）

日獣会誌 $32 \quad 661 \sim 670 \quad(1979)$ 


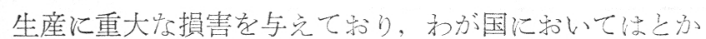
く双口吸虫による病害については軽視され斿らである が，今後は再検討が必要であるら。

\section{分 類}

FISCHOEDER (1901) 25) 1801 年に RUDOLPHI によっ て創設された属名 Amphistoma を改め, Paramphistomum とし, 従来知られていた哺乳類の双口吸虫を整理して Paramphistomidae 科法々めた。

その後, 多数の研究者により双口吸虫の分類上の位置 が種々検討されているが，大別すると双口吸虫を双口吸 虫科 (Family Paramphistomidae) 汇整理したもの(STUNKARD, 192563), FUHRMAN, 1928 ${ }^{27)}$, NÄSMARK, 1937 ${ }^{49)}$ ) と, 一段格上げして, 双口吸虫上科 (Superfamily Paramphistomoidea) に整理したもの (StILEs \& GoRdBERGer, 191062), Fukui, 1929 ${ }^{28)}$, Maplestone, 192347), Travassos, 1934 ${ }^{67)}$, Yamaguti, 1971 ${ }^{75)}$ )とに分けら机 る.とくに分類に新しい試又を取り入れた NÄSMARKは双 口吸虫を 1 科 13 亜科に分類し, 多数の新たな巠科, 属

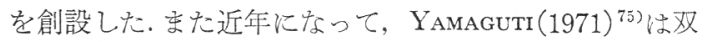
口吸虫上科を 3 科16亜科40属に細分している.

\section{形態および分布}

双口吸虫を大別する基本的な分類法として, STILES \&
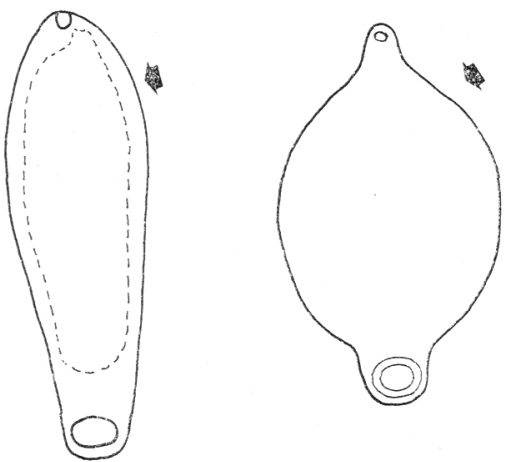

Gastrodiscidae 科型

Gastrothylacidae 科型

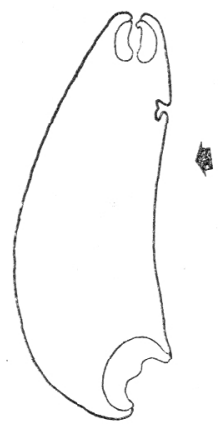

Paramphistomatidae 科型

図 1
GOLDBERGER（1910）年）次の上5な基準で分類してい,

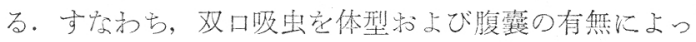
て分類し, 虫体が扁平で体が前体部之後体部に分かれ, 腹囊のないもの黉 Gastrodiscidae 科, 虫体が円錐形で, 前体部之後体部は区別されず，から腹霬のないるのを

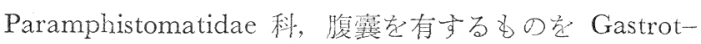
hylacidae 科として，3科汾计ている(図 1). 実際上， 双口四虫を大別するには上述の分類で十分であるが，種 類を同定するためには NÄSMARK $(1937)^{49)}$ の分類が役立 つ. NÄSMARK は和もに虫体の中央綎断切片の組織学的 検査によってロ吸盤を 17 型, 生殖腔を 22 型, 後吸盤を 22型に区分して，各竌らの各型の組合わせにより，また 口吸盘の直径と体長比, 後吸盤の直径と体長比などの違 いに重要学和いて双口四虫を分類している。今回は誌面 の関係上，双口吸虫の属種の鑑別点は割愛する。双口吸

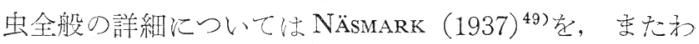
が国の主要種については茅根 (1979) ${ }^{11)}$ を参照されたい。

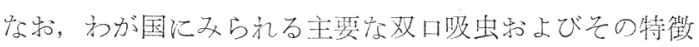
は表 2 兆よび図 2 に示す。

日本に分布する欢口吸虫としては從来, Paramphistomum gotoi, P. cervi, P. ichikawai, P. explanatum, Calicophoron calicophorum, Orthocoelium streptocoelium, O. orthocoelium, $O$. scoliocoelium, Fischoederius elongatus, F. cobboldii, F. japonicus, Homalogaster paloniae などが知られて和り, そのらちの

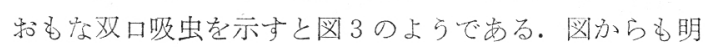
らかのよらに P. cervi, C. calicophorum, O. orthocoelium, F. elongatus 惊以前法日本に広範囲にわたって分布してい



1. Calicophoron calicophorum 2. Paramphistomum gotoi

3. Homalogaster paloniae 4. Orthocoelium streptocoelium 5. P. ichikawai 6. Fischoederius elongatus

网2 


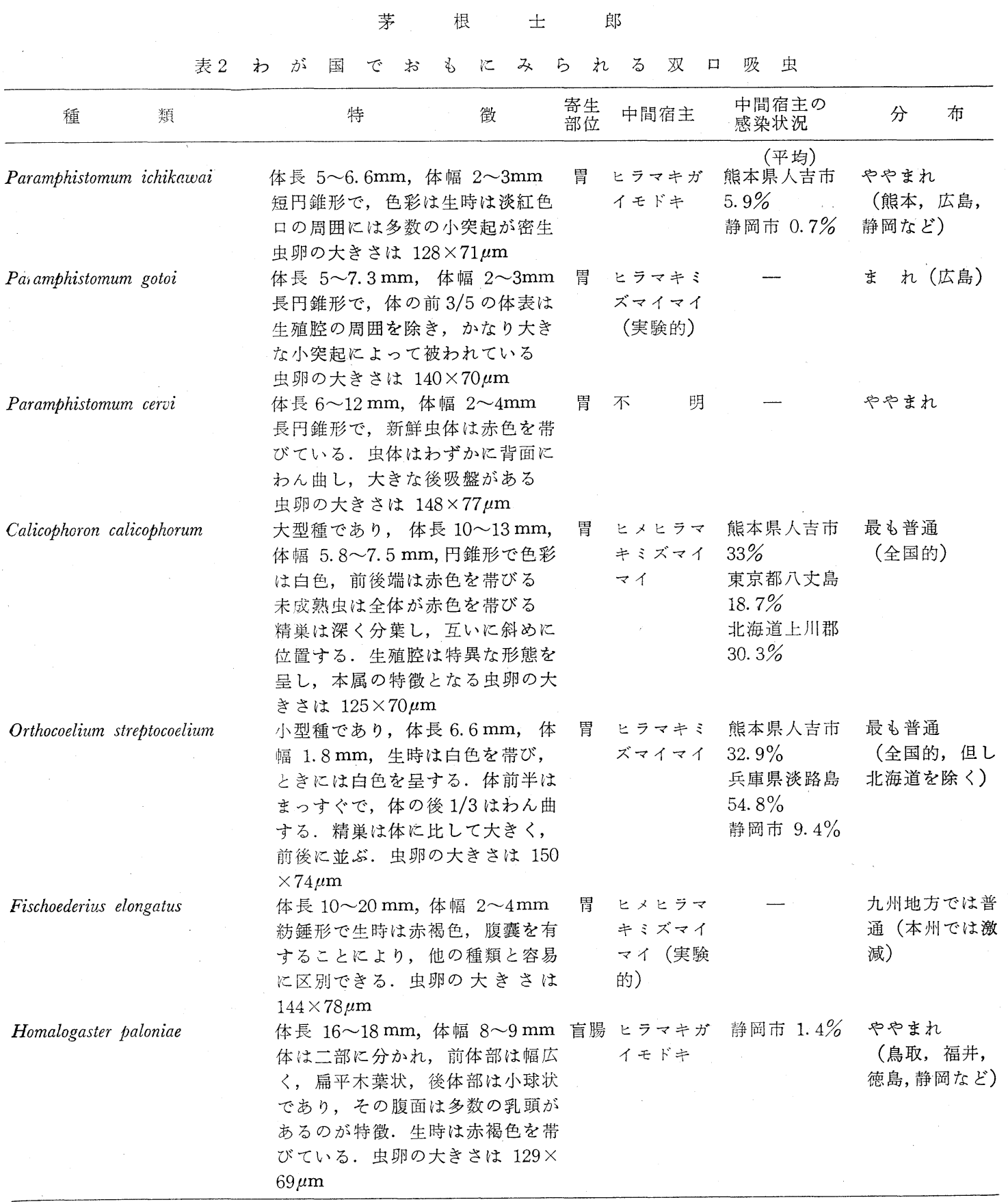

た.しかし近年, 著者らが中間宿主の検索就よ゙゙各地の と畜場から採取した虫体をもとに調べた結果ではP.cervi はきわめて少なく, 季た F. elongatus 恃本州では激減 乙, 九州地方に分布が限局されるなど, 双口吸虫の分布 汇変動がみられる.これら種類のらちでもC. calicophorum と O. streptocoelium の 2 種類は最も普通にみられ，末た 坂本ら (1964) ${ }^{57}$ によってわが国で最初に発見された平 腹双口吸虫 $H$. paloniae
傾向呅みれる。

\section{発䏍環}

哺乳類に寄生する双口吸虫の発育についての報告は, Looss (1896) ${ }^{45)}$ による Gastrodiscus aegyptiacus と'Paramphistomum cervi の中間宿主内での幼虫の記載が最初で めり, P. cervi の中間宿主は Physa alexandria と P. micropleura, G. aegyptiacus の中間宿主は Cleopatra bulimoides 


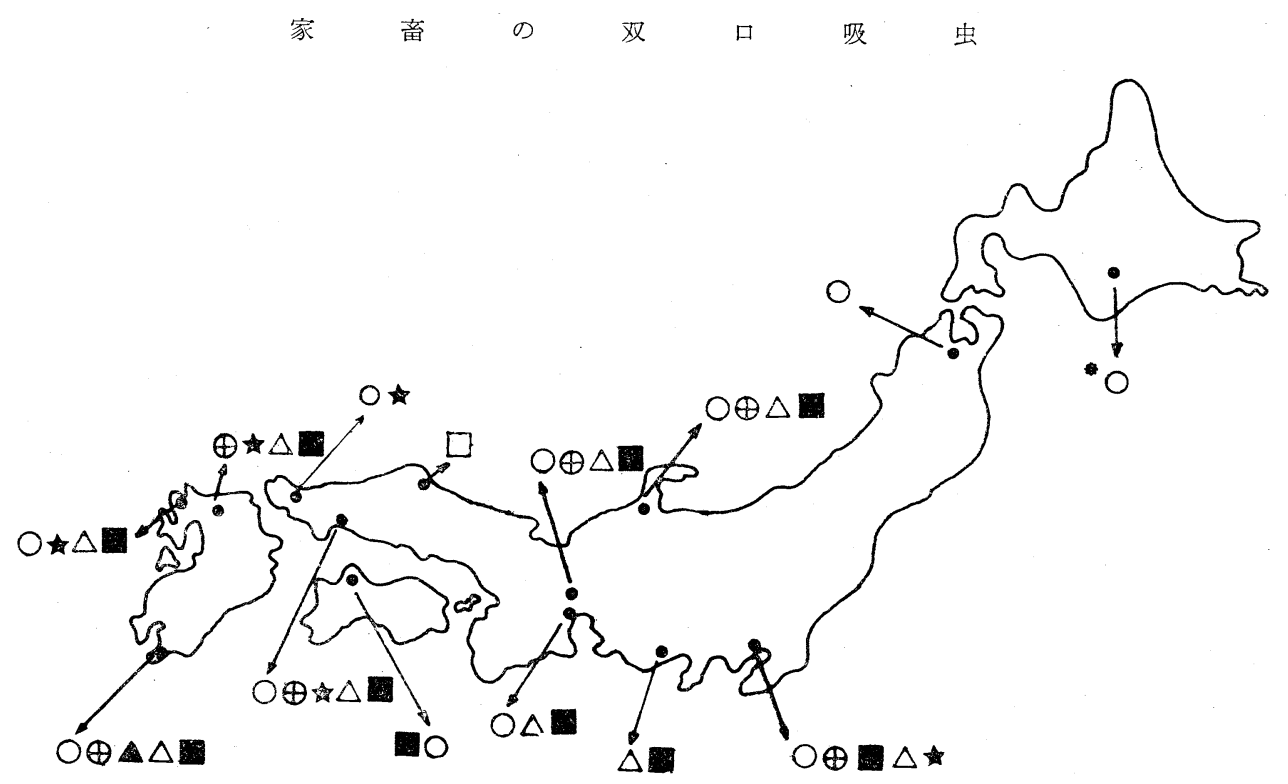

$\oplus$ Orthocoelium orthocoelium $\bigcirc$ Calicophoron calicophorum

- P. ichikawai $\triangle$ P. cervi Fischoederius elongatus

* 石本ら (1976) ${ }^{36)}$ は Calicophoron ijimai と同定している

O. streptocoelium $\star$ Paramphistomum gotoi 図3 従来, が国から報告された主要な双口吸虫の分布

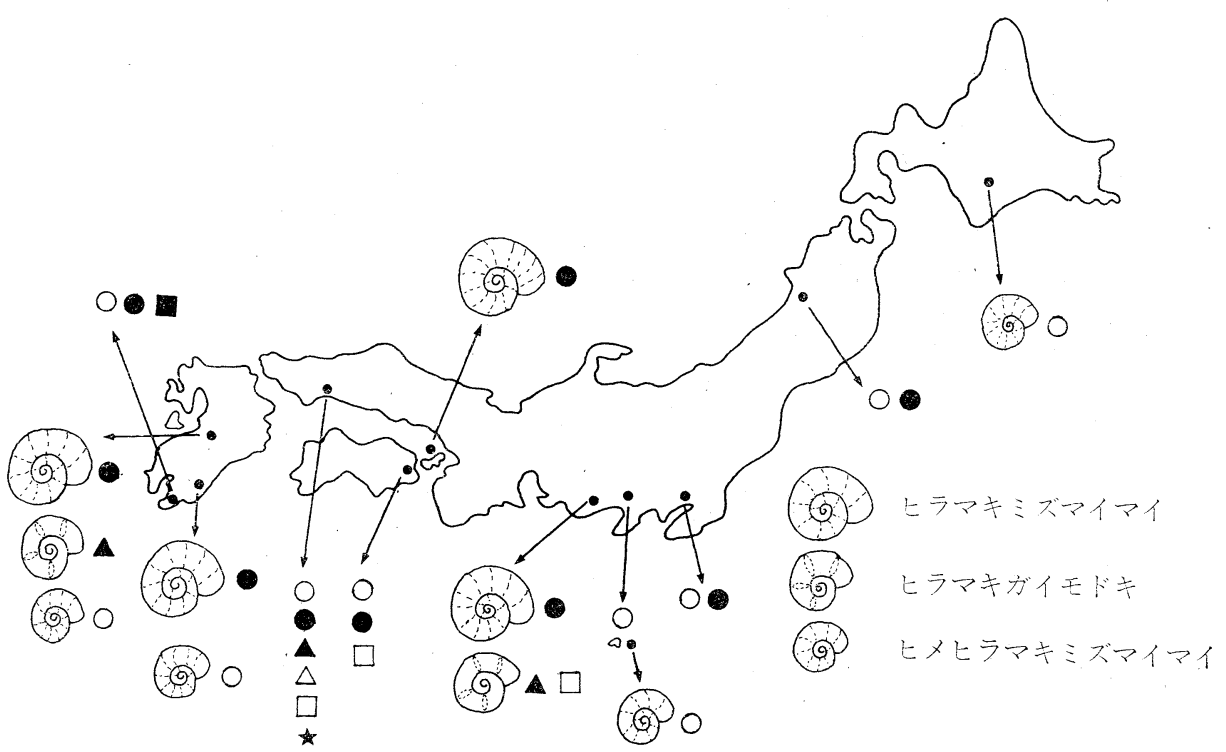

Calicophoron calicophorum

- Orthocoelium streptocoelium

* Paramphistomum gotoi

$\triangle P$. cervi

A P. ichikawai

Fischoederius elongatus

Homalogaster paloniae

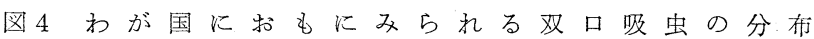

と C. cyclostomoides であることを明らかにしている.い っぽう, わが国での発育環についての最初の研究は高橋 (1927) ${ }^{65)}$ とって行なわれ，“Paramphistomum cervi”の中 間宿主はヒラマキミズマイマイ Gyraulus chinensis である ことが明らかになった。
双口吸虫の発育にはただ一つの吅間宿主である淡水巻 貝を必要とし，その発育環は肝蛙ときわめてよく似てい る.しかし，肝蛭などに比べて双口吸虫は種類がきわめ て豊富なため中間宿主となる貝の種類も多く，かつ分類 学的にも種々の科の巻貝を含んでいる. 世界的にみると 


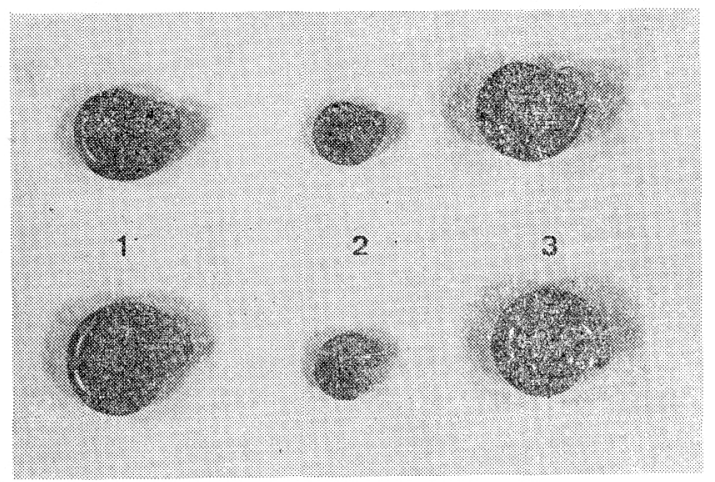

1. ヒラマキミズマイマイ Gyraulus chinensis

2. ヒメヒラマキミズマイマイ G. pulcher

3. とラマキモドキガイ Polypylis hemisphaerula

図 5

トウガタカワニナ科 Family Thiaridae, ヒラマキガイ科

Family Planorbidae, モノアラガイ科 Family Lymnaeidae, サカマキガイ科 Family Physidae の淡水産卷貝が 中間宿主になっている(表2)。かが国では見在までのと ころ 1 科 (Planorbidae 科) 2 属 (Gyraulus 属, Poly-

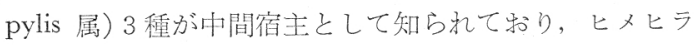
マキミズマイマイ Gyraulus pulcher は Calicophoron calicophorum 己 Fischoederius elongatus (実験的) の中間宿主で あり，ヒラマキミズマイマイ G. chinensis は Orthocoelium streptocoelium，ヒラマキガイモドキ Polypylis hemisphaerula は平腹双口吸虫 Homalogaster paloniae 2 Paramphistomum ichikawai の中間宿主である.

欢口吹虫の虫卵は大きく（種類によって異なるが 110 $\sim 150 \mu \mathrm{m})$, 卵蓋を有し, 無色, 透明で, 卵細胞の位管

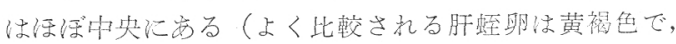

卵細胞の位置は中央部よりも畉蓋の近くにあることによ って区別される). 粪便中に排泄された虫卵の卵細胞は， すでに 4 〜 細胞に分裂している.

虫卵の発育は水温飞よって左右さ礼, Calicophoron ca-

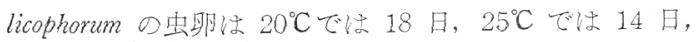
$30^{\circ} \mathrm{C}$ の場合は8日でミラシジウム (miracidium) が餒化 する。虫畉の餒化日数以双口吸虫の種類によっても多少 異なり, Paramphistomum microbothrium の虫莭では $27^{\circ} \mathrm{C}$ で 12 日 $^{64)}, 28^{\circ} \mathrm{C}$ で 17 日 $^{43)}, 26 \sim 28^{\circ} \mathrm{C}$ で $14 \sim 16$ 日 16), Cotylophoron colylophorum の虫畉では 28〜30 日 $^{69)}, \quad 27 \sim 32^{\circ} \mathrm{C}$ で $18 \sim 21$ 日 $^{61)}$ であり, P. ichikawai の場合には $27^{\circ} \mathrm{C} て ゙ 12$ 日 ${ }^{19)}, 33 \sim 39^{\circ} \mathrm{C}$ の高温では 5 日 40)でミラシジウムの邲化が始まることが報告されてい

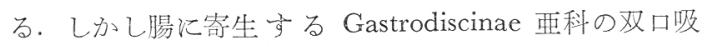
虫の中には高温で発育が阻害されるとの報告 ${ }^{23)} 3 ゙$ ひり, この科に属する平腹双口吸虫 $H$. paloniae 卵は培養水に 送気した場合にの夕順調に発育, 卵化することから, 胃
士 郎

内寄生の双口吸虫畉とは発育条件にかなり差異がみられ るよらである.

水中で餒化したミラシジウムの貝への侵入部位は種類 によって異なるよらである、P. microbothrium では貝の 呼吸腔をと和しての又侵入し ${ }^{16,43)}$, 頭部, 腹足, 触角か らは侵入しない43). 同様なことは Orthocoelium streptocoelium の場合でも報告されている19). しかし, Calicophoron calicophorum では呼吸腔ばかりではなく，頭部，腹 足, 触角などからも侵入する。 ミラシジゥムが貝に侵入 後, 6 時間以内汇繊毛のある外皮は脱落し，スポロシス 卜 (sporocyst) になる. 貝組織内で発育したスポロシス トはP. microbothrium では, 10 日43)ないし14 日坊で レジア (redia) が遊出する。后た P. ichikawaiでは8

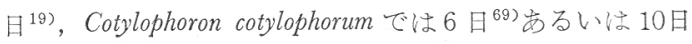
59), C. calicophorum では6 日, 平腹双口吸虫 H. paloniaeでは11日でレジアが遊出するという.

レジアは運動が活発で, 貝組織内を自由慟き回り, その体の後半部に㐫る多数の肧細胞はレジアの発育とと もに大きく発達する。娘レジア (daughter redia) の形 成については多数の研究者により観察されているが 16,19 , $23,46,52,53,61) ，$ 観察できなかったとの報告 59,607 西るる。

DURIE (1953) ${ }^{192}$ は中間宿主の高栄養物の摂取と飼育環境 の变化（急激な水温の低下）が娘レジアの産出を侹して いるのであろらと推察している.

セルカリア (cercaria)は未成熟な状態でレジアから貝 組織内遊出する. 七ルカリアの最初の遊出はP. microbothrium で 26 $6^{43)}$ ない 30 日 $^{16)}$ ，P. ichikawai では 15 日 ${ }^{19)}$ ， O. streptocoelium では $27^{\circ} \mathrm{C} て ゙ 21$ 日 $^{19)}, 17 \sim 21$ 日， Fischoederius elongatus では 13 日, C. calicophorum では 14 日，平腹双口吸虫では 20 日之報告されている。レジア から遊出した未成熟セルカリアは貝体内で発育し, 成 熟するまでに約 10 日前後を必要とする. 成熟したセル カリアは, 色素顆粒の沈着によって黑ない儿黑褐色を 耑び，一対の眼点が形成される，成熟セルカリアは貝の 呼吸腔を通じて外界に遊出する。 シラシジウムが貝に侵 入後, 七ルカリアが遊出する京でに要する日数はP. mi一 crobothrium では $28^{\circ} \mathrm{C}$ で 37 日 $^{43)}, 18 \sim 22^{\circ} \mathrm{C}$ で $43 \sim 46$ 日 16), C. calicophorum では $27^{\circ} \mathrm{C} て ゙ 28$ 日, P. ichikawai で は25 日 ${ }^{19)}$, Cotylophoron cotylophorum では 26 日 $^{69)}$, 30 日 $^{60)}, 30 \sim 35$ 日 $^{61)}$, 平腹双口吸虫 $H$. paloniae では 宝温飼育下で 32 日である。こ礼らの遊出日数の違いは 双口吸虫の種類が異なるといらことのほかに, 中間宿主 の飼育温度によって大いに左右され，DURIE（1953）19)は $27^{\circ} \mathrm{C}$ では O. streptocoelium のセルカリア遊出に要する日 数は 34 日で屴ったのに比べ, $20^{\circ} \mathrm{C} て ゙ は 63$ 日に遅延し たと述べている。

成熟七ルカリアは光の刺激によって感染貝から遊出し $19,22,43,61,69)$, 光度が強い汪どより多くのセルカリアが遊 
出する ${ }^{43)}$. 感染具に光を照射すると 2 〜時間でセルカ リアの遊出保ピークに達し ${ }^{43,64)}$, 大部分のセルカリアは 4 時間以内に遊出寸る ${ }^{16,43,64)}$. 七ルカリアの遊出時間は 午前 9. $00 \sim 11.00^{19)}$, 西い以午前 $11.00 \sim$ 午後 2.0069) が最も多いとされて家り, 弱アルカリ性を好及, $\mathrm{pH} 7.0$ 〜9.0の間でセルカリアの遊出が著しい69 といわれてい る. 感染具から遊出したセルカリアは活発に水中を泳 ぎ，光功最も強い水表面近くに群集する ${ }^{16)}$ 。 なたセル力 リアは黄色 ${ }^{20)}$, 黄色ないし緑色 ${ }^{432}$ の光に好えで群集し, 遊出後, 大部分は 30 分〜 1 時間以内に被囊する.

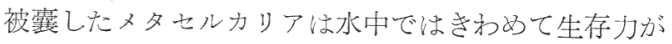
強く, P. microbothrium では 2 カ月間では大部分が, 5 カ月後では，少なくとも半数以下が生存する ${ }^{43)}$. た O. streptocoelium では最適条件のもとでは 3 力月19), $P$. ichikawai では 6 力月後も $32 \%$ が生存し ${ }^{19}$, Cotylophoron
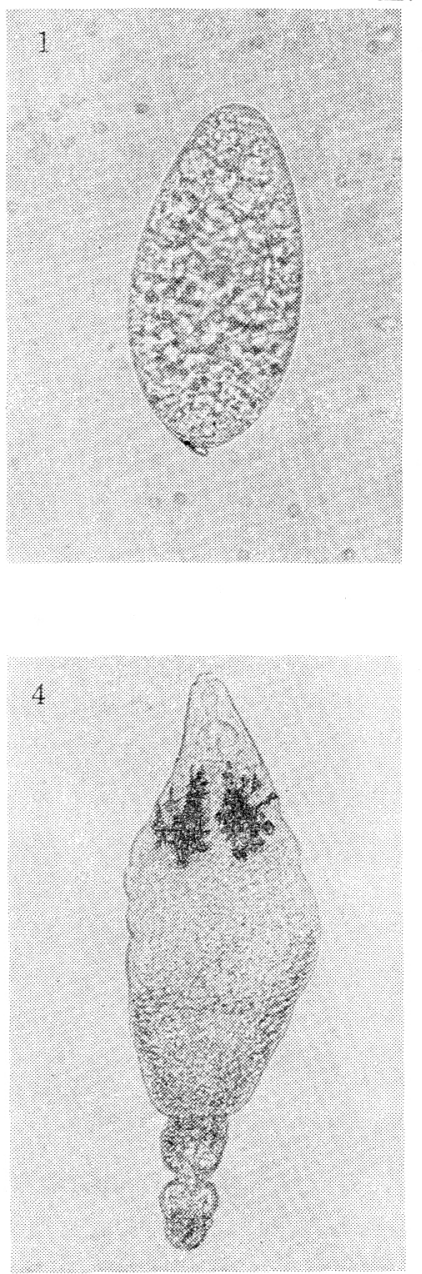

1. 虫卵 2 . スポロシスト (sporocyst)

5. 成熟セルカリア (mature cercaria)

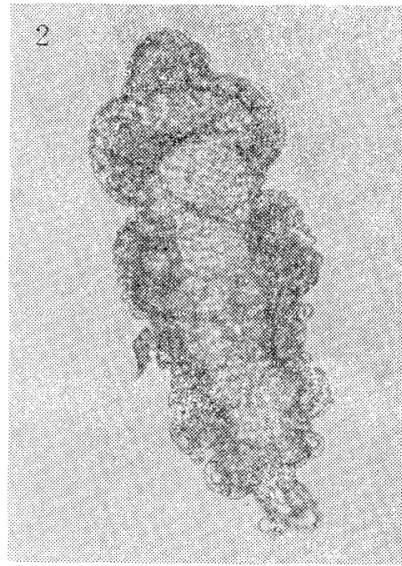

5

cotylophorum で法4 力月間以生存力ぶあると報告61 され ている、委たメタセルカリアは低温にむ比較的强く, $4^{\circ} \mathrm{C}$ で少㳊くとも29日間性存力に影響を受けないとされ ている29).

メタセルカリアが宿主に提取されると，幽門部から6 $\mathrm{m}$ 以内の小腸内で脱䘫し, 双口吸虫はまずこの部位に吸 着与る. 脱囊後4 日放 10 日目には急速に発育し, 小 腸の上方（幽門部から $3 \mathrm{~m}$ 以内）に移行する ${ }^{34)}$. 幼若虫 が十二指腸に停留する期間は 18 日から 42 日間であり 17), 感染後 17 日 $^{17)}$ 执よ゙ 20 日目 ${ }^{34)}$ から胃への移行を 開始し, 35 日後には大部分の虫体が胃へ移行する ${ }^{34)}$. ᄂ かし，きわ和て多数（20,000７0,000個）のメ夕世ルカ リアを感染させる P. microbothrium では牛で52日後で も大部分の虫体が小腸汇停留し， P. ichikawaiではめん 羊で感染後 4 〜 5 力月までは胃内へ移行せず，乙か子虫
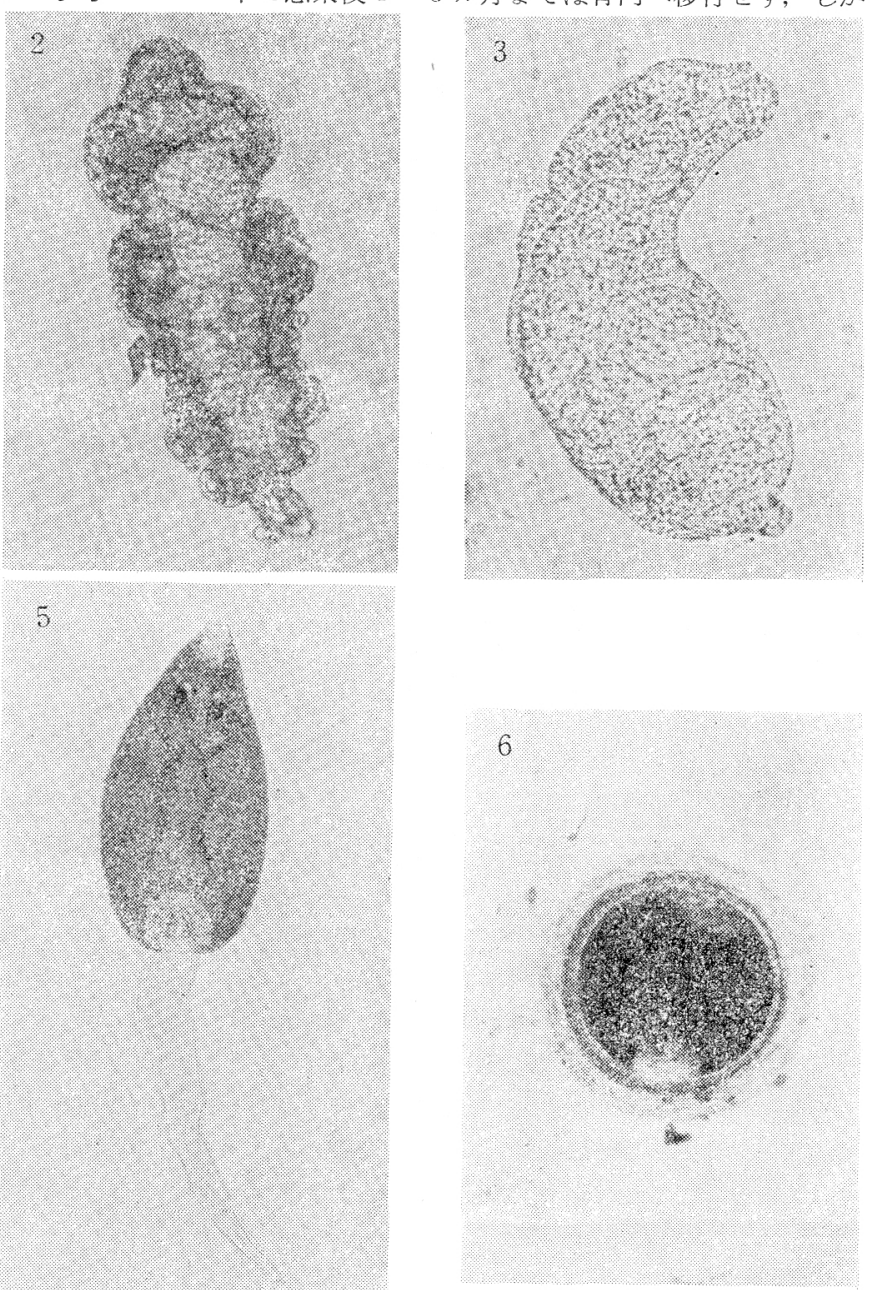

3. レジア (redia) 4. 未成熟セルカリア (immature cercaria) 6. メタセルカリア (metacercaria) 
茅根

体の発育が著しく遅延することが報告されている6).

また双口吸虫の好適宿主については HORAK (1967) ${ }^{34)}$

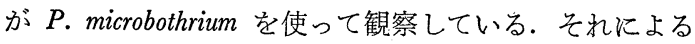
と感染後 4 21 日までは子牛の感染率は 49〜 $55 \%$ であ るのに比べ，めん羊では 62〜 72\%，山羊では 53〜 63\% と高く，乙か子子牛ではその後も $36 \sim 55.4 \%$ とほぼ平 均した感染率を保っているとるかかわらず，めん羊，山 羊での感染率は徐々に低下し, 感染後 97 日目にはめん 羊では $1.5 \%$ ，山羊では $4.7 \%$ であったと報告してい る.

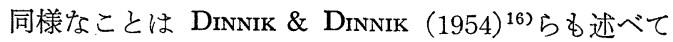
いるように, 山羊は本来, P. microbothrium に対して自 然抵抗性を持っているが牛はめん羊, 山羊に比べて双口 吸虫のより好適な宿主であるう。

メタセルカリア摂取後, 虫体が成熟して糞便中に虫卵 が排出されるまでに要する日数 (prepatent period) は双 口吸虫の種類拉よび宿主によって異なり，C. calicophorum

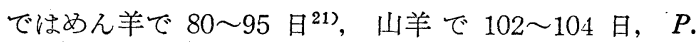
ichikawai ではめん羊で 49 51 日 ${ }^{19)}$, 山羊で 76〜77 日, P. microbothrium では牛で 56 日 $^{34)}$, 山羊で 69 日 $^{34)}$, め ん羊で 71 日年)であり, 腸に寄生する Gastrodiscus secundus ではロバで 98 日 $^{53)}$, 平腹双口吸虫 $H$. paloniae で は牛で 57〜94 日であるといわれている.

\section{症状}

胃内に寄生する成虫の病害性については，一般的には 無害 ${ }^{18)}$ とされて特り, 病理学的所見でる前胃粘膜の吸着 突起の形成と寄生部位にみられる乳頭の摩耗が主な病変 であって, 直接には病害を拈よぼしてはいないようであ $る^{3)}$.しかしながら，いっぽうでは立毛，多飲多渴症， 食欲不振, 胃弛緩症, 慢性胃炎, 貧血, 下顎浮腫などを 起こすとの報告もあり, きわめて多数が寄生した場 合 は, 前胃の消化吸収作用酒接または間接的濞影響を およぼす3)ともいわれて抢り，击ながちその病害性は無 視できないよらである.

多数の未成熟虫が小晹内に寄生したために起こる腸双 口吸虫症 (intestinal paramphistomiasis) の一般病状は, 元気㕵失, 食思不良, 立毛, 悪臭のある水様性下片が特 徵であり，この下痢は感染後16〜28日頃から始まり ${ }^{33)}$, 死亡するまで持続する. また回復した場合でも，数週間 は体重の減少が著しい33)、下痢便には，乙ばしば新鮮血 抢よび未成熟虫が含まれる。

剖検による観察では，小腸上部の腸壁は肥厚し，もろ くなり, しばしばカタール性渗出液で満され, 多数の未 成熟虫が粘膜表層あるいは筋肉内に深く侵入して寄生 し，ときには腹腔内に穿入しているのがみられる.この ため腸壁には多数の糜爛, 点状出血, 斑状出血が出現 し, またきわめて多数の感染例では腸䄉毛が完全に欠損
士 郎

する例も観察される ${ }^{33)}$.

一般的な臨床症状が現われるにはきわめて多数の未成 熟虫が奇生することが必要とされている. DinNik(1964) 18)は肝蛭 (F. gigantica) が子牛やめん羊に肝蛭症を起こ すためには 100 個のメタセルカリアの投与で十分である のに比べ, $P$. microbothriumのメタセルカリアでは100, 000 個の投与が必要であるとしている. 同様なことは $P . i c$ hikawai はめん羊に腸双口吸虫症を発症させるためには 少なくとも 7,200〜10,000 匹以上の未成熟虫の寄生污必 要であり ${ }^{6)}, P$. microbothrium がめん羊に寄生し症状を現 わし，死亡させるには，少なくとも40,000匹ないてそれ 以上の奇生が必要であるといわれている ${ }^{30)}$. また実験的 に牛を死亡させるには 100,000 匹の感染が必要であると の報告がある ${ }^{34)}$. このように腸双口吸虫症が発症するた めには子牛やめん羊, 山羊がきわめて大量のメタセルカ リアを摂取することが必要であり, 南アフリカ, ニニー ジーランド，オーストラリアなどの諸外国ではいずれも 放牧場内の沼沢地, 池川などの水源地の水面積が滅少す る乾期に, 中間宿主の貝が 1 力所に集まり, 水飲又場周 辺の牧草が大量のメタセルカリアで活染されるため発症 しやすいといわれている5,18,34).

腸双口吸虫症の症例は古くから報告があり, 最初の記 載はインドの BALDREY (1906) ${ }^{4)}$ と WALKER (1906) ${ }^{70)}$ らによって行なわれている，後に PANDE (1935) ${ }^{511}$ はこ れについて詳細な報告を行ない，それによると腸双口吸 虫症による死亡率は牛で 25～38\%，水牛で 10～20\%， 山羊で 17〜26\%であり，KATIYAR \& VARSHNEY(1961) 39)らによるとめん羊で $67.6 \%$ ，山羊で $75.5 \%$ であった といら.

オーストラリアでは EDGAR (1938) ${ }^{24)}$ が若牛 ( 1 才齢) の 30\% が，また ANON (1949)1) は感染した若牛（9〜 12 力月跉）の $50 \%$ のちの $20 \%$ が死亡したことを報告 し, また WITTEN (1955) ${ }^{72)}$ は. calicophorum に感染し た 250 頭の雌めん羊のうちの 35 頭が死亡したことを報 告している.

アフリカでも P. microbothrium 和よびその他の双口吸 虫が原因で成牛, 子牛, めん羊に腸双口吸虫症が起きた 多数の例の報告があり ${ }^{18)}$ ，それ以外にも北アメリカ ${ }^{55)}$,

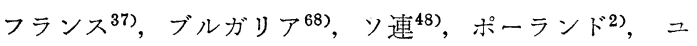
ーゴスラビア ${ }^{13)}$ など世界各地から数多くの症例が記載さ れている.

\section{駆虫薬}

双口吸虫の駆虫剤としては, 成虫, 未成熟虫のそれぞ れ，扣よび未成熟虫と成熟虫の両方に対して有効な三と 牤りの薬剂汭現在開発されている.

成虫に対して効果的な薬凨としては, 従来, hexachloroethane-bentonite 懸濁液 (OLSEN, 1949) ${ }^{50)}$, hexac- 
hlorophene (Bosman et al. 1961) ${ }^{7}$, bithionol(GuilHoN \& GRABER, 1962 $2^{38)}$, HoRAK, 1965 ${ }^{32)}$ ), neguvon (VIŠNJAKov \& IvANov, 1964 ${ }^{68)}$ ), bithionol $と$ hexachlorophene との併用 (TEUSCHER \& BERGER, 1965) ${ }^{66)}$ などが 報告されて和り，ごく最近には terenol (resorantel) の $65 \mathrm{mg} / \mathrm{kg}$ の投与が牛の胃内に寄生する Paramphistomum microbothrium そP. scotiae に対して高い駆虫効果がある ことが報告された（KoBULEI \& UdVARHELyi ${ }^{42)}, 1973$ ， Chroust $^{12)}$, 1973).

腸双口吸虫症の原因となる未成熟虫に対する薬剤とし ては Deusov (1955) ${ }^{15)}$ が Phenothiazine の $50 \mathrm{mg} / \mathrm{kg}$ を 3 日〜 5 日間隔で 3 回投与することによって, P. cervi の未成熟虫に対して 50\% の駆虫効果があったことを報 告している. とくに 1962 年以来, HorAK (1962) ${ }^{29)}$ ほ か多数の研究者により, hexachlorophene, bithionol, menichlopholan, niclosamide などが用いられ高い駆虫 効果があげられている。それによると HORAK (1962) 29) は, hexachlorophene の $20 \mathrm{mg} / \mathrm{kg} 1$ 回投与でめん羊の 小腸内の $P$. microbothrium の未成熟虫に対して駆虫率 43. $2 \% ， 2$ 回投与では $99.6 \%$ の効果方゙っったことを, また HoRAK (1965) ${ }^{32)}$ は bithionol の 25〜 $100 \mathrm{mg} / \mathrm{kg}$ の 1 回投与で, めん羊の P. microbathrium の未成熟, 成 熟虫に対して 92.7〜100\%の駆虫効果があったことを報 告している.

Menichlopholan については Boray (1969)6)が, 6mg/ $\mathrm{kg} 1$ 回投与でめん羊の小腸内の P. ichikawai 未成熟虫 に対して 95.7\% の駆虫率を得たが，胃内の成熟虫に対 しては，汪とんど駆虫効果がなく，42.7\%でめったこと を報告している。また, niclosamide (lintex, mansonil, yomesan) については KATIYAR \& GARG (1963) ${ }^{39)}$ が $50 \mathrm{mg} / \mathrm{kg} 1$ 回投与でめん羊の小腸之第四胃寄生の Gastrothylax crumenifer $と$ Cotylophoron cotylophorum の未成熟 虫に対して92.6\%の駆虫率をあげて和り，BORAY (1969) 6) も同様の薬剤を使用して $50 \mathrm{mg} / \mathrm{kg} 1$ 回投与で, めん 羊の小腸内の P. ichikawai の未成熟虫に対して $95.7 \%$ の高い駆虫効果を示すが，胃内の成虫に対しては $18.2 \%$ しか効果がなかったことを報告している. HoRAK(1962) 29) も同薬剂の $50 \mathrm{mg} / \mathrm{kg}$ の投与でめん羊の小腸および第 四胃の 20〜30 日齡の P. microbothrium の未成熟に対し ては 94. 2 99.7\% 辛駆虫効果があったのに対し, 胃内 の36 日荿令の未成熟虫に対しては效果がなかったことを 述べている.このよらに niclosamide の駆虫効果は必ず しも虫体の成熟度ばかりでなく, 虫体の寄生部位によっ ても左右されるようである. 同様なことは HORAK (1964) 31)が freon BU (freon 112 の異性体) をめん羊に 330 $\mathrm{mg} / \mathrm{kg}$ を等量の流動パラフィンに混ぜて投与した結果, 胃内の成熟等よび未成熟虫に対しては 99.6〜100\%の高 い駆虫效果があったにもかかわらず，第四胃の未成熟虫
に対する駆虫効果は 0 98.0\%と効果がまちまちであっ たことを述べているが，このことは薬剤の種類により， 寄生部位に対する薬剤効果が異なるためであろら.

以上の成績はめん羊の小腸に寄生する未成熟虫に対し ての成績であり，牛の小腸内に寄生する未成熟虫につい ては, PoPOV ら (1966) ${ }^{54)}$ が tremanol (bithionol+2, 4diclorophenol) の $50 \mathrm{mg} / \mathrm{kg}$ 投与が P. cervi と Calicophoron sp. の未成熟虫と成熟虫に対して $100 \%$ の効果が あったことを報告している，乙かし未成熟虫に対する駆 虫効果試験は人工感染牛を必要とするためか, 各種双口 吸虫に対して，一様に効果的な駆虫剂についての報告は 少なく，今後検討すべき問題であろう.

\section{診断および予防}

成虫寄生の確実な診断は, 糞便検査によって虫卵を検 出することである. 粪便中の虫卵数 (EP G) は感染後 の日数, 家畜の種類によって異なり, 牛はめん羊, 山羊 に比べて少ない. 糞便 $1 \mathrm{~g}$ 中の虫畉数は観便の採取時 刻によっても異なり, 午前中よりる日中ないし午前に増 加するので ${ }^{34,71)}$, 採糞は午後に実施し, 最低 $10 \mathrm{~g}$ の䔬 便を用いて感染の有無を調べる必要がある.

感染初期や，きわめて多数のメタ.セルカリアの感染を 受けた場合には, 虫体は未成熟状態のます長期間にわた って寄生するため, 虫卵は検出できないので, 食欲不振 と悪臭のある水様性下痢, 下痢便による篮部々後肢の污 れなどの臨床症状によって腸双口吸虫症を疑う。また未 成熟虫の排泄は診断の一助となる. 未成熟虫を検出する には, 大量の糞便 (250g) を採取し, 深底の大きなガラ スびんに入れ, 水を加党て粪便液の上清が透明になるま で水を何回も交換する. 次に上清を捨て, 沈殿物を精査 することにより, 約 $3 \sim 4 \mathrm{~mm}$ の大きさの圭成熟虫が観 察される (BORAY, 1959) ${ }^{5}$. しかし, より確実な診断は, 死後の剖検によって, 十二指腸内に多数の未成熟虫を検 出することである。

\section{予防}

わが国では，双口吸虫の感染源としては水田内に棲息 する中間宿主貝を介して, 稲わら, 畔畔雑草に付着した メタセルカリアを家畜ぶ摂食する場合と, 放牧地内の沼 沢池, 池などに棲息する中間宿主貝を介して, メタセル カリアに活染された水飲及場周辺の牧草および雑草を摂 食することにより感染する二とおりのタイプがある．前 者の場合には粪便の処置, 中間宿主貝の殺滅, メタセル カリアの付着した稲わら, 畦畔雑草の給与の禁止などで 十分であるが，後者の場合には上述の方法は実行不可能 であり，また中間宿主貝の感染率がきわめて高いことも あって, 腸双口吸虫症を発生しやすい.したがって予防法 としては污染源となる成牛の双口吸虫を駆除することが 
必要である。

$$
\text { 文献 }
$$

1) Anon.: Agric. Gaz. N.S.W., 60, 438 (1949).

2) Anczykowski, F. \& Chowaniec, W.: Med. vet., Varsovie., 11, 531 535 (1955) [BoRAy, 1959 より].

3) 芦沢, ほか：宮崎大農研時報, 15, 201 216(1968).

4) Baldrey, F.S.H.: J. Trop. Vet. Sci., 1, 388 (1906) [BorAy, 1959より].

5) Boray, J.C.: Aust. vet. J., 35, 282 287 (1959).

6) Boray, J.C.: Vet. Med. Review, No. 4, 290 308 (1969).

7) Bosman, C.J., et al.: J.S. Afr. vet. med. Ass., 32, $227 \sim 233$ (1961).

8) Butler, R.W. \& Yeoman, G.H.: Vet. Rec., 74, 227 231 (1962).

9) Chinone, S. \& Itagaki, H.: Jap. J. Vet. Sci., 39, 665 670 (1977).

10）茅根，㴗か：麻獣大研報，2，317３25 (1977).

11）茅根：獣医臨床寄生虫学（獣医臨床寄生虫学編委 員会編）140～155，文永堂（1979）.

12) Chroust, K.: Acta Veterinaria, Prno, 42, 281 286 (1973).

13) Cvetkovik, LJ.: Vet. Glasn., 22, $41 \sim 49$ (1968) [HORAK, 1971より].

14) Dawes, B.: The trematoda, London, Cambridge University Press (1946).

15) Deusov, N.L.: Veterinariya, Moscow, 32, 36 37 (1955) [HoRAK, 1971 ょり].

16) Dinnik, J.A. \& Dinnik, N.N.: Parasitology, 44, 285 299 (1954).

17) Dinnik, J.A. \& Dinnik, N.N.: Bull. epizoot. Dis. Afr., 10, 27 31 (1962).

18) Dinnik, J.A.: Bull. epizoot. Dis. Afr., 12, 439 454 (1964).

19) Durie, P.H.: Aust. J. Zool., 1, 193 222 (1953).

20) Durie, P.H.: Aust. J. Agric. Res., 6, 200 202 (1955).

21) Durie, P.H.: Aust. J. Zool., 4, 152 157 (1956).

22) Dutt, S.C. \& SRivastava, H.D.: J. Helminth., 40, 45 52 (1966).

23) Dutt, S.C., Srivastava, H.D.: J. Helminth., 46, 35 46 (1972).

24) Edgar, G.: Aust. vet. J., 14, 27〜31 (1938).

25) Fischoeder, F.: Zool. Anz. Bd., 24, 367 375 (1901).

26) Fischoeder, F.: Zool. Jahrb. (Syst.) 17, 485 660 (1903).

27) Funrman, O.: Trematoda. Handbuch der Zoologie, Bd., II, 101 102 (1928).

28) Fukui, T.: Jap. J. Zool., 2, 1 351 (1929).

29) Horak, I.G.: Onderstepoort J. vet. Res., 29, 197 202 (1962).

30) Horak, I.G. \& Clark, R.: Onderstepoort J. vet. Res., 30, 145 159 (1963).

31) Horak, I.G.: J.S. Afr. vet. med. Ass., 35, $161 \sim$
166 (1964).

32) Horak, I.G.: J.S. Afr. vet. med. Ass., 36, 561 566 (1965).

33) Horak, I.G.: J.S. Afr. vet. med. Ass., 37, 428 430 (1966).

34) Horak, L.G.: Onderstepoort J. vet. Res., 34, $451 \sim 540$ (1967).

35) Horak, I. G.: Advances in Parasitology, 9, 33 72, London, Academic Press (1971).

36) 石本, 大林：北獣会誌, 20, 6 11 (1976).

37) Guilhon, J. \& Priouzeau, M.: Rec. Med. vet., 121, 225 (1945) [BORAY, 1959 より].

38) Guilhon, J. \& Graber, M.: Bull. Acad. vet. Fr., 35, 275 278 (1962).

39) Kattyar, R.D. \& VArshney, T.R.: Indian vet. Sci., 33, 94 98 (1963).

40) Kisilev, N.P.: Veterinariya, Moscow, 44, 51 53 (1967).

41) Klimenko, V.V. \& Velichko, I.V.: Parazitologiya, 6, 291 296 (1972).

42) Kobulei, T. \& Udvarhelyi, J.: Magyar Allatorvosok Lapja, 28, 325 327 (1973) [Abst. Helminth., 44 (1975) Abstr. No. 303].

43) Lengy, J.: Bull. Res. Coun. Israel, 9B, 71 130 (1960).

44) Le Roux, P.L.: Res. vet. Res. Un. S. Afr., 16, 243 253 (1930).

45) Looss, A.: Mem. Inst. Egypt., 3, 252 (1896) [Fukui, 1929 より].

46) Malek, E.A.: J. Parasit., 57, 975 979 (1971).

47) Maplestone, P.A.: Ann. Trop. Med. Parasit., $17,113 \sim 212$ (1923).

48) Mereminskin, A.I. \& Gluzman, I.Y.: Veterinariya, Kiev., No. 11, 41 43 (1967) [HoRAK, 1971 より].

49) NÄSMARK, K.E.: Zool. Bidr. Uppsala, 16, 301 566 (1937).

50) Olsen, O.W.: Vet. Med., 44, 108 109 (1949).

51) Pande, P.G.: Indian J. vet. Sci., 5, 364 375 (1935).

52) Peter, C.T. \& Mudaliar, S.V.: Curr. Sci., 17, 303 304 (1948).

53) Péter, C.T.: Ind. J. Helm., 12, 18〜50 (1960).

54) Popov, A., et al.: Veterinarno Meditsinski Nauki, 3, $813 \sim 818$ (1966).

55) Price, E.W.: J. Parasit., 30, 119 (1944).

56) Price, E.W. \& McIntosh, A.: J. Parasit., 30 (Suppl.) 9 (1944).

57) 坂本, ほ加: 寄生虫誌, 13, 501 506 (1964).

58) Simson, W.A.: Vet. Rec., 6, 748 (1926).

59) Singh, K.S.: J. Parasit., 44, $210 \sim 224$ (1958).

60) SinHA, B.B.: Indian J. vet. Sci., 20, $1 \sim 11$ (1950).

61) Srivastava, H.D.: Indian J. vet. Sci., 8, 381 385 (1938).

62) Stiles, W. \& Goldberger, J.: Hyg. Lab. Bull., No. 68, 1 261 (1910). 


\section{犬膵 臓の若年性腺房性萎縮症の二例}

63) Stunkard, H.W.: Parasitology, 17, 137 148 (1925).

64) Swart, P.J. \& Reineke, R.K.: Onderstepoort J. vet. Res., 29, 189 195 (1962).

65) 高橋 : 福岡医誌, 20, 617 640 (1927).

66) Teuscher, E. \& Berger, J.: Bull. epizoot. Dis. Afr., 13, 45 54 (1965).

67) Travassos, L.: Mem. do Inst. Oswald Cruz., 29, $19 \sim 178$ (1934).

68) Višnjakov, J. \& Ivanov, V.: Angew. Parasit., 5, 220 227 (1964) [HoRAK, 1971 上り].

69) Varma, A.K.: J. Helminth, 35, 161 168 (1961).

70) Walker, G. K.: J. Trop. vet. Sci., 1, 410 (1906) [BORAY, 1959 より].

71) Willmott, S. \& Pester, F.R.N.: J. Helminth., 26, $147 \sim 156$ (1952).

72) Witten, L.K.: $\quad$ N.Z. vet. J., 3, 144 (1955).

73) Yamagutr, S.: Jap. J. Med. Sci., Vl, Bact. \& Parasit., 1, 131 151 (1939).

74) Yamaguti, S.: Thapar Commem, 1953, 301 304 (1953).

75) Yamaguti, S.: Synopsis of Degenetic Trematodes of Vertebrates, Vol. 1, 696 714, Tokyo, Keigaku Publ. (1971).

\section{犬膵 臓 の若 年 性腺房性萎縮 症 の二例}

\section{橋本 晃* 喜多 功* 岡田幸助** 藤本 㭌**}

(昭和 54 年 6 月 15 日受理)

Two Canine Cases of Juvenile Acinar Atrophy of Pancreas

Akira Hashimoto et al. (Faculty of Agriculture, Gifu University, Kakamihara Gifu 504, et al.)

\section{SUMMARY}

A 10 -month-old Akita bitch and a 13-month-old shepherd male were suffering from the malabsorption syndrome. Laboratory tests revealed mild anemia, hypoproteinemia, and hypocholesteremia. A serious insufficiency in pancreatic enzymes was suggested. No diabetic signs were noticed, but a hypofunction of sugar decomposition was exhibited.

Pathologically, the pancreas was highly atrophic with principal changes in acinar cells. These cells contained pale unclei and slightly basophilic cytoplasm. Islands of langerhans remained unchanged. Electron microscopy revealed the presence of multivesicular cells with specific morphology. Nothing abnormal was seen in the pancreatic ducts, blood vessels, or peripheral nerves.
ANDERSON と LOW ${ }^{1}$ は「膵臓の若年性萎縮症」とい ら病名のもとに, 若齡犬に発生する非炎症性の膵蔵酵素 欠乏症候群を特徵とする疾病を報告している，本病は脺 臓外分泌機能の欠落により消化障害を起こす結 果, 多 食, 体重減少, 脂肪性下痢便扝よび食䔬症の諸症状を現 わすのを特徽としている。この種の膵臓疾患については TöRÖK（1936 年 ${ }^{18)}$ の報告を嚆矢として, 膵臓萎縮症 ${ }^{12}$, ${ }^{16,19)}$, 膵臓の腺房性萎縮症 ${ }^{20)}$, 若年性膵臓腺房萎縮症 ${ }^{14}$, 萃臓の変性性萎縮症 7 , 膵臓の腺房組織の虚脱症あるい は萎縮症 ${ }^{17)}$ ，扣よび萎縮性膵臓炎 ${ }^{3)}$ などの病名で，これ まで多数の報告がある.

著者らも, 本病とみなされる臨床経歴の明らかな 2 症 例に遭遇したので, その臨床的ならびに病理学的所見に

* 岐皁大学農学部 (岐阜県各務原市那加門前町 1)

** 北海渞大学獣医学部 (札幌市北区北18条西 9 丁目)
ついて報告する.なお，本例の電顕像についてはすでに 報告したら)ので，ここでは代表的な所見の記戴にとどめ ることとする.

\section{検索 材料おむび方法}

症例の病歴：症例 1 は秋田種の雌犬で, 初診時 10 力 月龄であった，食欲良好であるにもか斿らず，この 1 カ月の間に急にやせてきたといら禀告で, 本学家畜病院 に来院した，この時には，削瘦と低蛋白血症の他に特記 すべき所見は認められなかった。患犬は妊娠 1 力月であ った. 出産後, 下痢便の持続, 削瘦の進行, 食䔬症が認 められたといら禀告で, 初診から 2 カ月後に再来した. 萃機能不全による吸収不良症候群と診断し, 治療を行な ったが, 衰弱が進行し, 初診から 2 力月半で安楽死の処 置をとった。 